Asian Pacific Journal of Reproduction

Journal homepage: www.apjr.net

\title{
Efficacy of anti-microbial agents on vaginal microorganisms and reproductive performance of synchronized estrus ewes
}

\author{
Mohammed KM ${ }^{\bowtie}$, Nabih AM, Darwish GM \\ Animal Reproduction Research Institute (ARRI), Giza, AL-Haram, Egypt
}

\section{ARTICLE INFO}

Article history:

Received 16 February 2017

Revision 12 March 2017

Accepted 21 April 2017

Available online 1 May 2017

Keywords:

Sheep

Estrus synchronization

Reproductive performance

Antimicrobial

Fungus

\begin{abstract}
Objective: To isolate and identify microflora and fungal species at different phases during estrus synchronization of ewes and estimate their prevalence; compare the effectiveness of antimicrobial administration to intravaginal sponge on the changes in the vaginal microorganisms and reproductive performance. Methods: Sixty Egyptian ewes were allocated into three equal groups (G: 1, 2 and 3). G1 was inserted with vaginal sponge containing medroxyprogesterone acetate and served as control; without antimicrobial additive. The other two groups were treated as G1, but sponges were previously injected with ciprofloxacin (G2), while sponges of G3 were injected with ciprofloxacin and clotrimazole. Vaginal swabs were collected from each treated ewe, prior sponge insertion, at sponge withdrawal and $48 \mathrm{~h}$ later for microbiological investigation and bacterial count. On the day of sponge removal, 300 IU/eCG was administered for each treated ewe. The identified bacterial strains before sponge insertion were tested for sensitivity with antimicrobial disks. Results: Bacterial isolates before sponge insertion were more sensitive to ciprofloxacin. Frequencies of ewes in estrus; the interval from sponge withdrawal to onset estrus and the duration of estrus were statistically similar among treated groups. The pregnancy rate in G2 (100.0\%) was higher than G1 (66.7\%) and G3 (82.4\%). The total bacterial count before sponge insertion was similar between all treatments and increased significantly in all groups on the day of sponge withdraw. The prevailing bacteria on D0, D14 and $48 \mathrm{~h}$ after sponge removal for all treated groups were Staphylococcus spp. followed by Escherichia coli. Regarding to fungus species, percentages of isolation increased from $5.00 \%$ (before sponge insertion) to $100.00 \%$ and $88.89 \%$ at sponge withdraw for G1 and $\mathrm{G} 2$, respectively. In G3, the fungus was declined from $10 \%$ (before sponge insertion) to $5 \%$ (at sponge removal). Conclusions: The concomitant treatments by antimicrobial to the vaginal sponge which used for estrus synchronization in ewes can improve reproductive performance.
\end{abstract}

\section{Introduction}

Intravaginal sponge impregnated with progestogens being the most commonly used for estrus synchronization in sheep[1-3]. Sponges containing progestagens are used for long periods of similar lifespan to a cyclic corpus luteum, regardless of the stage of the cycle or the follicular status of the ovary at the time of treatment[4]. The presence of these sponges in the vagina for this period acts as a foreign body and constitutes a predisposing factor for vaginitis and generates changes in the vaginal environment with accumulation of purulent mucous secretion, and foul smelling fluids. This infection is often

\footnotetext{
Corresponding author: K.M. Mohammed, Animal Reproduction Research Institute (ARRI), Giza, AL-Haram, Egypt.

Tel: 00201007440472

E-mail : kamel14@hotmail.com
}

due to proliferation of the local microbiota and by secondary opportunistic Gram negative Enterobacteriaceae invaders, mainly Escherichia coli (E. coli)[1,5-7]. Coliforms, as well as Gram-positive cocci, mainly Staphylococcus spp. and Streptococcus spp., are the most common bacterial species present in those infections[6]. Changes in these bacteria of the vagina and its population with the abnormal vaginal flow were correlated to a high incidence of

This is an open access article distributed under the terms of the Creative Common Attribution-Non Commercial-Share Alike 3.0 License, which allows others to remix, tweak and buid upon the work non-commercially, as long as the author is credited and the new creations are licensed under the identical terms.

For reprints contact: reprints@medknow.com

(C2017 Asian Pacific Journal of Reproduction Produced by Wolters Kluwer- Medknow

How to cite this article: Mohammed KM, Nabih AM, Darwish GM. Efficacy of anti-microbial agents on vaginal microorganisms and reproductive performance of synchronized estrus ewes. Asian Pac J Reprod 2017; 6(3): 121-127. 
unfertilized ova in artificially inseminated ewes, with impaired embryo development and subsequent decrese fertility rates of estrus synchronized ewes[8]. In some laboratories and commercial products manufacturers recommend that to avoid vaginitis and decreases the perceived odour at sponge withdrawal, antibiotics should be added to sponges before insertion to the vagina. Although tetracycline is antibiotic, most widely used in association with sponge treatments, there are several studies reporting that it is the antibiotic with the greatest number of resistant colonies[7,9,10] and this may explain the decrease in conception rates after its application. Others observed the application of gentamycin to vaginal sponges is efficient in preventing vaginal infections provoked by intravaginal sponge[11]. Thus, the objectives of the study were to determine, characterize the vaginal bacterial flora in native ewes at the time of sponge insertion for estrus synchronization and subsequent in vitro bacterial susceptibility to different antibiotics. Changes in the bacteria and fungus population at different stages (sponges withdrawal and estrus) following intravaginal sponge insertion with different antimicrobial treatment; and evaluating the bacteria and fungus effects on the subsequent reproductive performance were also investigated.

\section{Materials and methods}

\subsection{Animals management and study location}

The study was conducted on a total 60 multiparous, non-pregnant native Egyptian ewes, aged 3-5 years and weighing 35-45 kg. The animals were clinically healthy, free from reproductive disorders and fed on maintenance ration containing Egyptian clover plus concentrate mixture with $16.6 \%$ crude protein. Water and mineral supplement were available ad-libitum. The present study was carried out during spring months (late March to May) at the Animal Reproduction Research Institute, Giza province (located at latitude of $30^{\circ} 00^{\prime} 29^{\prime} \mathrm{N}$, longitude of $31^{\circ} 12^{\prime} 39^{\prime \prime} \mathrm{E}$, altitude of $30 \mathrm{~m}$ above sea level).

\subsection{Experimental design and treatment schedule}

The ewes were randomly allocated into three groups (G1, G2 and G3) of equal numbers ( $n=20$ ewes/each group). G1 was inserted by the aid of an applicator with polyurethane vaginal sponge containing $30 \mathrm{mg}$ medroxy-progesterone acetate; MAP (DEPO-PROVERA, Pfizer), and served as a control with no antimicrobial addition to the vaginal sponge. The applicator was disinfected with ethyl alcohol $70 \%$ between consecutive ewes treatment. The other two groups were treated with vaginal sponges as $\mathrm{G} 1$, but sponges were previously injected with $0.5 \mathrm{~mL}(50 \mathrm{mg})$ ciprofloxacin (Arab pesticides and veterinary drugs) for $\mathrm{G} 2$ and $0.5 \mathrm{~mL}(50 \mathrm{mg}$ ) ciprofloxacin plus 0.5 $\mathrm{mL}(5 \mathrm{mg}$ ) clotrimazole as antimycotic drug (Bayer) for G3. Vaginal sponges were left in situ for $14 \mathrm{~d}$ in all treated groups. The antibiotic and the antimycotic drugs were injected at the middle part of the sponges then distributed in the whole sponge.

Prior to sponge insertion (day of insertion was recorded as day 0) and at time of sponge withdraw (day of removal was recorded as day
14) as well as $48 \mathrm{~h}$ after sponge withdraw (time of expected estrus); vaginal samples were taken for micro-organisms investigation. On the day of sponge removal, 300 IU/eCG (Gonaser, Hipra, Girona Spain) was administered S/C for each ewe of all treated groups as a schedule for estrus synchronization. Estrus was recorded with the aid of a ram, twice a day for $30 \mathrm{~min}$. Three rams of proven fertility were used for breeding. The ewes which observed in estrus in each treatment were divided into three groups for natural insemination (4-6 ewes/ram). Pregnancy was checked on day 35 after mating by ultrasonography using a real time B-Mode ultrasound equipped with a stiffened 7.5 MHZ linear array trans-rectal probe (Pie Medical LC 100, The Netherlands).

\subsection{Parameters related to reproductive performance}

Estrus response (\%): Number of ewes exhibiting estrus/total ewes in each treatment group $\times 100$; Time to onset estrus $(\mathrm{h})$ : Onset estrus is the time elapsed between the cessation of the treatment (sponge withdrawal) to the first positive signs of estrus; Duration of estrus (h): Defined as the period of sexual receptivity and mating which characterized by distinct behavioral symptoms of estrus and estimated from first to last signs of estrus; Pregnancy rate: (pregnant ewes/ewes mated) $\times 100$; Lambing rate: (lambed ewes/pregnant ewes) $\times 100$; Fecundity rate: (number of lambs born/number of pregnant ewes) $\times 100$.

\subsection{Collection of vaginal samples}

Aseptically vaginal samples were collected from the posterior vaginal region of each ewe individually, using sterile pressed cotton swabs, moistened with sterile saline solution by direct contact against the vaginal wall, and then transported in sterile containers to the microbiology laboratory within $1 \mathrm{~h}$. Samples were collected from all the treated ewes immediately prior to sponge insertion, at sponge withdrawal and $48 \mathrm{~h}$ later (day of expected estrus).

\subsection{Bacterial count}

For total bacterial count (colony forming units; $\mathrm{CFU} / \mathrm{mL}$ ), the first vaginal swab was vigorously homogenized by mechanical vortexing, diluted in $1 \mathrm{~mL}$ sterile phosphate buffered saline, $\mathrm{pH} 7.4$, for 1 min. in order to suspend the bacteria. The resulting suspension was serially diluted and then seeded in Petri dishes containing standard plate count media and blood agar media for $48 \mathrm{~h}$ in a bacteriological incubator at $37{ }^{\circ} \mathrm{C}$. The total bacterial count $(\mathrm{CFU} / \mathrm{mL})$ was done using a manual bacterial colony count procedure according to Koneman et al.[12].

\subsection{Bacterial isolation and identification}

The second vaginal swab was cultured using different media for isolation and purification of bacteria included: Blood agar, MacConkey agar, Nutrient agar, Edward blood agar and Mannitol salt agar. Plates were incubated at $37{ }^{\circ} \mathrm{C}$, and examined daily for bacterial growth, for a period of $3 \mathrm{~d}$ for bacterial isolation[13]. All 
bacterial genera isolates were identified on the basis of colony characteristics, Gram staining, and biochemical reactions, including: urease test; citrate test; indole test, motility test, nitrate test, catalase activity tests, the fermentation of carbohydrates; and triple sugar iron. Genera were classified according to Martins et al.[7] and Cruickshank et al.[14]. All media used for bacterial isolation, identification and count are produced by Oxoid company.

\subsection{Antibiotic sensitivity test}

Vaginal bacterial flora is seldom recovered as single isolates and often they are isolated as mixed bacteria. Therefore, to determine the most appropriate antibiotic that has the ability to eliminate the vaginal flora, the identified strains isolated (before sponge insertion) as single or mixed bacteria were tested for sensitivity in vitro with antimicrobial agents according to Derbala[15]. Panel of fourteen antimicrobial different disks of the most frequently used antimicrobials and by diffusion method with Mueller-Hinton agar (Merck, Sao Paulo, SP, Brazil) in accordance with the protocols of Clinical and Laboratory Standards Institute: AMC: Amoxicillin + Clavulanic acid; AML: Amoxicillin; A/S: Ampicillin +Sulbictam; OT: Oxytetracycilline; C: Chloramphenicol; CIP: Ciprofloxacin; OFX:Ofloxacin;CEQ:Cefquinome; CX:Cloxacillin; E: Erythromycin; G: Gentamycin. NOR: Norfloxacin; AK: Amikacin; and NE: Neomycin.

\subsection{Fungal isolation}

All vaginal swabs were inoculated on plates of Sabouraud dextrose agar containing antibiotic and incubated at $25{ }^{\circ} \mathrm{C}$ for $7 \mathrm{~d}$. The first examinations of the plate were done after $2 \mathrm{~d}$ to determine the degree of fungal growth. Representative growth was isolated on Sabouraud dextrose agar slopes for further identification according to Samson[16].

\subsection{Statistical analyses}

SPSS 10.0.1 software was used for all data statistical analyses. The effects of the treatments on the onset of estrus, duration of estrus and total bacterial count were statistically analyzed using analysis of variance, with the GLM General factorial procedure of SPSS and post hoc mean comparisons were performed using Duncan test. Estrus response, pregnancy, lambing and fecundity rates were compared between treatment groups using the chi-square test. Statistical significance was defined as $P<0.05$.

\section{Results}

The current work was carried out on sixty ewes, three of them (one from G1 and two from G2) were excluded as vaginal sponge fall and not present inside vagina at the time of sponge withdraw, where in the treatment G3 no sponges losses occurred. Comparing the frequency of isolation of each microorganism in the present study, the bacterial culture of the vaginal swabs before sponge insertion showed the most prevalent isolates of bacterial flora was Staphylococcus spp. $(43 / 57 ; 70.43 \%)$ which recorded as a summation for both single and mixed isolates, whereas the incidence of $E$. coli and Streptococcus isolated as mixed with other bacteria were $24 / 57(42.11 \%)$ and 19/57 (33.33\%), respectively, and only 4 out $57(7.00 \%)$ of vaginal swabs before sponge insertion shown fungus isolation (Table 1).

Table 1

Incidence of single and mixed bacterial isolates and fungal isolates from vagina of ewes before sponges insertion.

\begin{tabular}{lrr}
\hline Bacterial isolates & no. & $\%$ \\
\hline Single isolates & & \\
Staphylococcus spp. & $10 / 57$ & 17.54 \\
Streptococcus spp. & $0 / 57$ & 0.00 \\
E. coli & $0 / 57$ & 0.00 \\
Pseudomonas spp. & $0 / 57$ & 0.00 \\
Klebsiella spp. & $0 / 57$ & 0.00 \\
Mixed isolates & & \\
Staphylococcus spp. + Streptococcus spp. & $9 / 57$ & 15.79 \\
Staphylococcus spp. + E. coli & $14 / 57$ & 24.56 \\
Staphylococcus spp. + Streptococcus spp. + E.coli & $10 / 57$ & 17.54 \\
No bacterial growth & $14 / 57$ & 24.56 \\
Fungal isolates & & \\
Asperigillus fumigatus & $0 / 57$ & 0.00 \\
Penicillinum spp. & $2 / 57$ & 3.51 \\
Alternaria spp. & $0 / 57$ & 0.00 \\
Cladosporium spp. & $2 / 57$ & 3.51 \\
\hline
\end{tabular}

The most vaginal isolated bacteria showed sensitivity to Ciprofloxacin (13/43; 30.23\%), Cefoquinome (7/43; 16.28\%), Ofloxacin $(6 / 43 ; 13.95 \%)$, Amoxicillin/Clavulanic acid (5/43; $11.63 \%)$ and Gentamycin $(4 / 43 ; 9.30 \%)$, whereas less than $7.00 \%$ of bacterial isolates were sensitive to Amikacin, Norfloxacin, Oxytetracycillin and Ampicillin/Sulbictam. Indeed, only one drug (Ciprofloxacin) was highly susceptible and effective against the majority of isolates (Table 2). However, the vaginal bacteria isolates were resistant to Amoxicillin, Chloramphenicol, Cloxacillin, Erythromycin, and Neomycin (Table 2).

Generally and regardless antimicrobial treatment in this study, the prevailing bacteria on D0 (day of sponge insertion), D14 (day of sponge withdraw) and $48 \mathrm{~h}$ after sponges removal (day of expected estrus) for all treated groups were Gram positive Staphylococcus spp. followed by Gram negative E. coli and Gram negative Streptococcus spp. (Table 3). Comparing to G1 (without antimicrobial agent), G2 (Sponge containing ciprofloxacin) and G3 (Sponge containing ciprofloxacin plus antimycotic) showed marked decreases in these bacteria on day of sponge withdraw and the day of expected estrus (48 $\mathrm{h}$ after sponge removal). On the other side, G3 clearly showed lower isolation of fungus on day 14 and day of estrus than G1 and G2 (Table 3). Regarding to fungus isolation and identification, as shown in Table 3, results of the current work recorded that, percentages of isolation increased from $5.26 \%(1 / 19)$ as penicillinum spp. only (before sponge insertion) to $15.79 \%(3 / 19)$ for the same fungus species. In addition to $11 / 19(57.89 \%), 5 / 19$ (26.32\%) and 1/19 (5.26\%) for Cladosporium spp., Aspergillus spp. and Alternaria 
Table 2

Efficacy of antibiotics on single and mixed bacterial isolates from vagina of ewes before application of vaginal sponge for estrus synchronization.

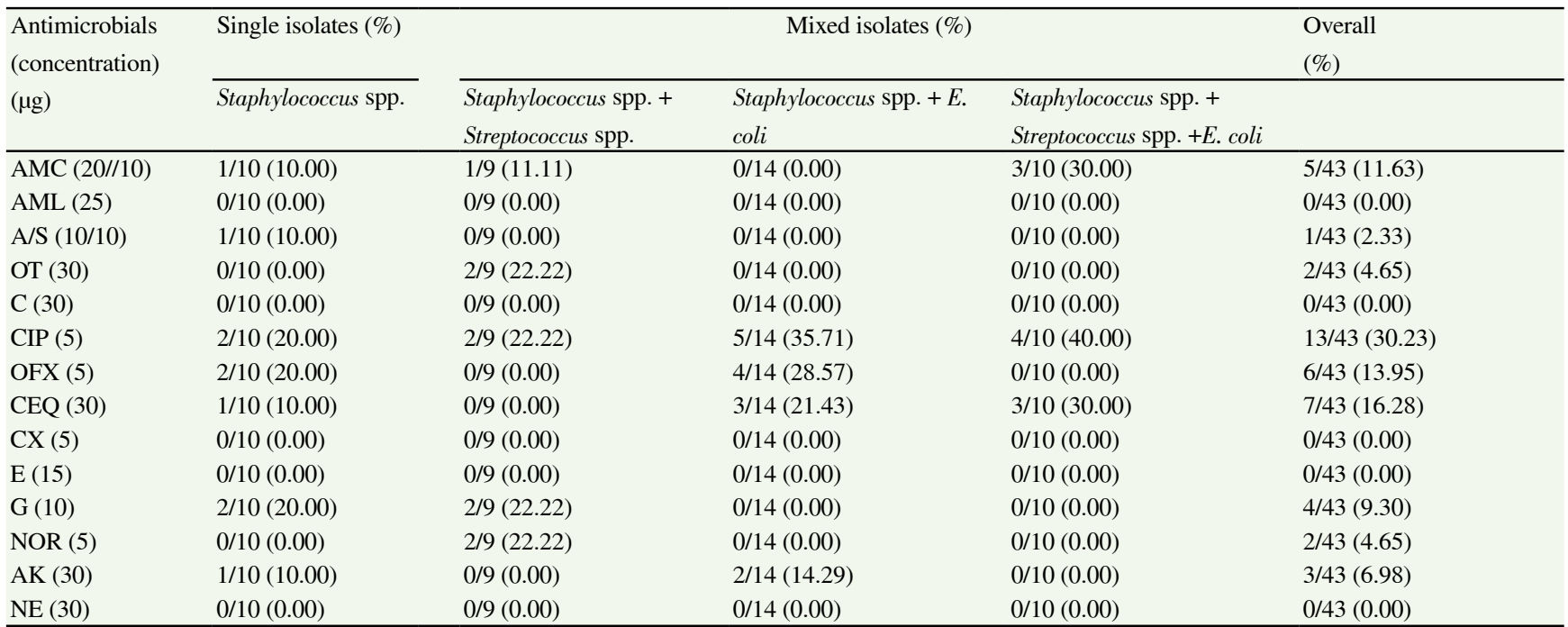

AMC: Amoxicillin + Clavulanic acid; AML:Amoxicillin; A/S: Ampicillin +Sulbictam; OT: Oxytetracycilline; C: Chloramphenicol; CIP: Ciprofloxacin; OFX: Ofloxacin; CEQ: Cefquinome; CX: Cloxacillin; E: Erythromycin; G:Gentamycin. NOR:Norfloxacin; AK:Amikacin; NE: Neomycin.

Table 3

Incidence of bacterial and fungal isolates from vagina of ewes at different days of sponge's treatment.

\begin{tabular}{|c|c|c|c|c|c|c|c|c|c|}
\hline \multirow{2}{*}{$\begin{array}{l}\text { Sponge antibiotics } \\
\text { contents }\end{array}$} & \multicolumn{3}{|c|}{ G1: without antimicrobial treatment $(\%)$} & \multicolumn{3}{|c|}{ G2: Ciprofloxacin (\%) } & \multicolumn{3}{|c|}{ G3: Ciprofloxacin+ Clotrimazole $(\%)$} \\
\hline & D0 & D14 & $\mathrm{DE}$ & D0 & D14 & $\mathrm{DE}$ & D0 & D14 & $\mathrm{DE}$ \\
\hline \multicolumn{10}{|l|}{ Gram positive cocci } \\
\hline Staphylococcus spp. & $14 / 19(73.68)$ & $17 / 19(89.47)$ & $12 / 19(63.16)$ & $14 / 18(77.78)$ & $4 / 18(22.22)$ & $1 / 18(5.56)$ & $15 / 20(75.00)$ & $5 / 20(25.00)$ & $2 / 20(10.00)$ \\
\hline Streptococcus spp. & $6 / 19(31.58)$ & $10 / 19(52.63)$ & $5 / 19(26.32)$ & $6 / 18(33.33)$ & $3 / 18(16.67)$ & $1 / 18(5.56)$ & $7 / 20(35 . .00)$ & $3 / 20(15.00)$ & $1 / 20(5.00)$ \\
\hline \multicolumn{10}{|l|}{ Gram negative bacilli } \\
\hline E. coli & $8 / 19(42.11)$ & $10 / 19(52.63)$ & $8 / 19(42.11)$ & $8 / 18(44.44)$ & $5 / 18(27.78)$ & $2 / 18(11.11)$ & $8 / 20(40.00)$ & $7 / 20(35.00)$ & $3 / 20(15.00)$ \\
\hline Pseudomonas aeruginosa & $0 / 19(0.00)$ & $1 / 19(5.26)$ & $0 / 19(0.00)$ & $0 / 18(0.00)$ & $1 / 18(5.56)$ & $1 / 18(5.56)$ & $0 / 20(0.00)$ & $0 / 20(0.00)$ & $0 / 20(0.00)$ \\
\hline \multicolumn{10}{|l|}{ Fungus } \\
\hline Aspergillus fumigatus & $0 / 19(0.00)$ & $5 / 19(26.32)$ & $3 / 19(1$ & $0 / 18(0.00)$ & $10 / 18(55.56)$ & $7 / 18$ & $0 / 20(0.00)$ & $0 / 20(0.00)$ & $0 / 20(0.00)$ \\
\hline Penicillinum spp. & $1 / 19(5.26)$ & 3/19 (15.79) & $1 / 19(5.26)$ & $0 / 18(0.00)$ & 2/18 (11.11) & $1 / 18(5.56)$ & $1 / 20(5.00)$ & $0 / 20(0.00)$ & $0 / 20(0.00)$ \\
\hline Alternaria spp. & $0 / 19(0.00)$ & $1 / 19(5.26)$ & $0 / 19(0.00)$ & $0 / 18(0.00)$ & $1 / 18(5.56)$ & $1 / 18(5.56)$ & $0 / 20(0.0)$ & $0 / 20(0.00)$ & $0 / 20(0.00)$ \\
\hline Cladosporium spp. & $0 / 19(0.00)$ & $11 / 19(57.89)$ & $4 / 19(21.05)$ & $1 / 18(5.56)$ & $3 / 18(16.67)$ & $2 / 18(11.11)$ & $1 / 20(5.00)$ & $1 / 20(5.00)$ & $1 / 20(5.00)$ \\
\hline
\end{tabular}

D0: Day of sponge insertion; D14: Day of sponge withdraws; DE: $48 \mathrm{~h}$ after sponge withdraw.

spp., respectively at time of sponges withdrawal for G1 (without antimicrobial). Meanwhile, in G2 (sponges injected with Ciprofloxacin), the type of fungus isolated was Cladosporium spp. only $1 / 18(5.56 \%)$ before sponges insertion, increased to $3 / 18(16.67 \%)$ for the same fungus species. In addition to $10 / 18$ (55.56\%), $2 / 18$ (11.11\%) and 1/18 (5.56\%) for Aspergillus spp., Penicillinum spp., and Alternaria spp., respectively at sponges withdrawal (day 14). On the other hand, fungus isolates from G3 (sponges injected with Ciprofloxacin plus Clotrimazole) nearly cleared $(1 / 20 ; 5 \%)$ from fungus at day of sponges withdrawal and at estrus day (Table 3). It means the pattern was changed in G3 (ciprofloxacin/clotrimazole), where the isolation of fungus before sponge insertion was $10 \%$ and declined to $5 \%$ at day of sponge removal.

The total bacterial counts before sponge insertion were $18.14 \times 10^{4} /$ $\mathrm{mL}, 18.06 \times 10^{4} / \mathrm{mL}$ and $19.94 \times 10^{4} / \mathrm{mL}$ for G1 (control; without antimicrobial), 2 (ciprofloxacin) and 3 (antimycotic/ciprofloxacin), respectively (Table 4 ), these counts were significantly increased $(P<0.05)$ at the time of sponge removal for all treated groups (Table 4). Indeed, these increases were relatively, i.e. G1 recorded the highest increases $\left(68.57 \times 10^{4} / \mathrm{mL}\right)$ followed by G3 $\left(39.40 \times 10^{4} / \mathrm{mL}\right)$ and G2 $\left(33.51 \times 10^{4} / \mathrm{mL}\right)$. However, these counts declined to its lower levels at the time of estrus for groups 2 and 3, which were relatively similar to that of day of sponge insertion for group 1 (Table 4).

Table 4

Incidence of bacterial count $\left(\times 10^{4}\right)$ isolates from vagina of ewes at different days of sponges treatment (means $\pm \mathrm{SE}$ ).

\begin{tabular}{llll}
\hline \multirow{2}{*}{ Treatment groups } & \multicolumn{3}{c}{ Stages of sponge treatment } \\
\cline { 2 - 4 } & $\begin{array}{l}\text { Before sponge } \\
\text { insertion }\end{array}$ & $\begin{array}{l}\text { Day of sponge } \\
\text { withdraw }\end{array}$ & $\begin{array}{l}48 \mathrm{~h} \text { after sponge } \\
\text { withdraw }\end{array}$ \\
\hline G1 (Control) & $18.14 \pm 3.20^{\mathrm{b}}$ & $68.57 \pm 16.08^{\mathrm{a}}$ & $17.41 \pm 3.63^{\mathrm{b}}$ \\
G2 (Ciprofloxacin) & $18.06 \pm 2.44^{\mathrm{b}}$ & $33.51 \pm 8.98^{\mathrm{a}}$ & $13.63 \pm 2.34^{\mathrm{c}}$ \\
G3 (Ciprofloxacin// & $19.94 \pm 1.17^{\mathrm{b}}$ & $39.40 \pm 2.70^{\mathrm{a}}$ & $15.76 \pm 1.26^{\mathrm{c}}$ \\
\hline Clotrimazole) & & & \\
\hline
\end{tabular}

Means in the same raw followed by different superscripts $a, b, c$ are significantly different $(P<0.05)$.

The overall mean percentage of ewes observed in estrus was $80.7 \%$ and the frequencies of ewes came into estrus were similar among the ewe groups (Table 5). The interval from sponge withdrawal to onset 
of estrus, duration of estrus, lambing and fecundity rates were not different among treated groups (Table 5). However, the pregnancy rate for ewes received sponge injected with ciprofloxacin (G2) was higher (100.0\%) than control; G1 (66.7\%) and that received sponges containing combination of antimycotic plus ciprofloxacin; G3 $(82.4 \%)$. In the same manner, as shown in (Table 5), the lambing rate was higher in ciprofloxacin treated ewes group; G2 (92.9\%) than control without antimicrobial; Gl (80.0\%) and G3 (78.6\%).

Table 5

Efficacy of vaginal sponge antimicrobial treatments used for estrus synchronization on reproductive performance of treated ewes.

\begin{tabular}{|c|c|c|c|c|}
\hline \multirow{4}{*}{ Parameters } & \multicolumn{3}{|c|}{ Sponge antimicrobial contents } & \multirow[t]{4}{*}{ Overall } \\
\hline & \multirow{3}{*}{$\begin{array}{l}\text { G1: Without } \\
\text { antimicrobial }\end{array}$} & \multirow{3}{*}{$\begin{array}{c}\text { G2: } \\
\text { Ciprofloxacin }\end{array}$} & \multirow{3}{*}{$\begin{array}{c}\text { G3: } \\
\text { Ciprofloxacin/ } \\
\text { Clotrimazole }\end{array}$} & \\
\hline & & & & \\
\hline & & & & \\
\hline Estrus response (\%) & $15 / 19(78.9)$ & $14 / 18(77.8)$ & $17 / 20(85.0)$ & $46 / 57(80.7)$ \\
\hline Time to onset & $39.73 \pm 1.56$ & $39.85 \pm 1.61$ & $40.64 \pm 1.46$ & $40.08 \pm 0.89$ \\
\hline \multicolumn{5}{|l|}{ estrus $/ \mathrm{h}$ (means $\pm \mathrm{SE})$} \\
\hline Duration of estrus/h & $30.80 \pm 1.90$ & $32.57 \pm 1.97$ & $28.12 \pm 1.79$ & $30.50 \pm 1.09$ \\
\hline \multicolumn{5}{|l|}{ (means $\pm \mathrm{SE}$ ) } \\
\hline Pregnancy rate $(\%)$ & $10 / 15(66.7)$ & $14 / 14(100.0)$ & $14 / 17(82.4)$ & $38 / 46(82.6)$ \\
\hline Lambing rate $(\%)$ & $8 / 10(80.0)$ & 13/14 (92.9) & $11 / 14(78.6)$ & $32 / 38(84.2)$ \\
\hline Fecundity rate $(\%)$ & $9 / 10(90.0)$ & $14 / 14(100.0)$ & $13 / 14(92.9)$ & $36 / 38(94.7)$ \\
\hline
\end{tabular}

\section{Discussion}

The most prevalent bacterial isolates before sponge insertion were Staphylococcus spp. (70.43\%) followed by E.coli $(42.11 \%)$ and Streptococcus spp. (3.33\%). The fungus was isolated from $7 \%$ of vaginal swabs before sponge insertion. In the same pattern, Oliveira $e t$ al.[10] found the predominant bacteria isolated before sponge insertion was Gram positive which constitute $63.6 \%$ (21/33 isolates), while the Gram negative bacteria showed $33.4 \%$ (12/33 isolates). Moreover, Majeed et al.[17] found the most prevalent bacterium belonged to the genus Staphylococcus spp. before sponge insertion was $57.9 \%$ (22/38 isolates), while the Gram negative bacteria showed $42.1 \%$ (16/38 isolates). However, Manes et al.[1] reported more than $90.0 \%$ (19/21 isolates) of the bacterial flora present at device insertion was mainly Gram positive, contrary the Gram negative bacteria was $0 \%$. With regards to antimicrobial sensitivity, results herein and other studies[10] revealed that, Staphylococcus spp. were members of the normal vaginal microbes of small ruminants, so it is necessary to prevent the growth of opportunistic microorganisms such as E. coli. The concomitant use of antimicrobial is often suggested to reduce the undesirable effects caused by the sponges[5,7]. The identified strains of vaginal bacterial flora obtained in this study either as single isolate or mixed (more than one bacterial colony type) were tested for sensitivity in vitro with fourteen different antibiotics. Ciprofloxacin was effective against the majority of bacterial flora isolates before sponge insertion followed by Cefoquinome and Ofloxacin, while gentamycin is the third rank. This finding is consistent with previous reports by Carson et al.[18], Gabriel Martins et al.[19] and Bruno Penna et al.[20]. On the other side, Suarez et al.[5] recorded Gentamycin and cefazolin were the most effective compounds to prevent bacterial growth following the use of progestin impregnated intravaginal sponges in ewes. However, the concomitant use of antibiotics is often suggested to reduce the undesirable effects caused by the sponges, but this practice may induce antibiotic resistance[5,7]. It is well known that antimicrobial drugs are frequently overused for other indications, including diarrhea and respiratory diseases, which could have contributed to selection of resistant strains in the microbiota. Subsequently, there is a paucity of studies regarding antimicrobial susceptibility of bacteria isolated from the vagina of ewes may vary not only due to the primary incriminating factor, but also with the region where the study was conducted. Similar observations have been observed by Majeed et al.[17] and Oliveira et al.[10]. However, the flora present after the local use of antibiotics is completely different to that observed in the vagina of ewes with spontaneous estrus[1]. These changes in the vaginal flora patterns which associated with estrus synchronization may be affected by many factors. Suarez et al.[5]reported that the hormonal changes status, such as estrus cycle could effect on vaginal bacterial population, especially when progesterone levels were high, as progesterone suppresses specific components of the immune system and natural killer cell activity[21]. Ultimately, Lewis[22] and Pineda[23] suggested that progestogens analogues have immune suppressive effects and may alter the vaginal bacterial flora. All vaginal sponges used herein containing MAP as progestagens for estrus synchronization so we can assume that MAP sponge content induced the same effects to all ewe groups, so the variation in the result findings are attributed to antimicrobial sponge content and sponge itself rather than MAP.

Fungus isolations generally showed dramatically decreases in G1, 2 and 3, two days after sponge removal. This may be by the exerting effect of estrogen, which increased at these phases (proestrus and estrus) inducing surprising increases in local immune response for all treated groups, and this effects promoted by antimycotic containing vaginal sponge in treating ewes of G3. It is noticeable the application of ciprofloxacin alone increases the incidence of fungus isolation, as totally $61.11 \%$ at estrus phase compared to control group (42.11\%) and ciprofloxacin/ clotrimazole (5\%). Likewise, Glover and Larsen[24] concluded that the extensive antibiotic use posed little risk for the development of fungus infection. In the same line, Jinping et $a l .[25]$ hypothesized that baseline fungus culture obtained from vagina requiring antibiotic therapy may develop symptomatic vulvovaginal mycotic infection after antibiotic therapy. Similarly, Bluestein et al.[26] reported $35 \%$ fungus colonization at baseline increased to $50 \%$ after $10 \mathrm{~d}$ of antibiotic therapy. To our knowledge, this is the first prospective cohort study applied antimicrobial [(ciprofloxacin and antimitotic) contents vaginal sponge for estrus synchronization in ewes in Egypt and being monitored for fungus isolation and compared results to a control group of ewes that not exposed to antibiotics. The total bacterial count was significantly decreased $(P<0.05)$ at the time of estrus (mating) compared to the time before sponge insertion in ciprofloxacin ewes (G2) and antimycotic/ ciprofloxacin ewes (G3), whereas, in the control group (G1; without antimicrobial) this counts were relatively similar. In another study related to ewes, it was observed that bacterial populations returned to numbers similar to those observed before sponge insertion $2 \mathrm{~d}$ after 
sponge withdrawal[27,28]. Furthermore, Manes et al.[1] recorded that, the $\mathrm{pH}$ of the vaginal flow on day of sponge insertion and before insemination showed no significant differences between treatments.

The total bacteria count obtained from samples collected on D0 was similar between all treatments and increased significantly in all groups at the end of the period (D14; day of sponge withdraw). However, two $d$ after sponge removal the vaginal bacterial population returned to levels similar to those observed prior to their insertion in the control group. These results are in agreement with those observed by Martins et al.[7], Amin[27] and Martins et al.[29]. This reduction in the CFU may be due to the removal of the irritating agent (sponge, or vaginal device) and promoted by physiologically surprising through the increase in local immune response caused by the estrogenic effects during proestrus and estrus phases. Actually, groups treated with antimicrobial agents used in this study showed a significantly decrease $(P<0.05)$ in $\mathrm{CFU}$ counts $48 \mathrm{~h}$ after sponge withdraw than those before sponge insertion, and this may be due to the effects of the antimicrobial agents (ciprofloxacin with/without antimycotic) to additionally other previously mentioned factors. The frequencies of ewes came into estrus were relatively similar among ewe groups. Moreover, the interval from sponge withdrawal to onset estrus and the duration of estrus were not different among groups. Similarly, Nihat Ozyurtlu et al.[30] recorded that the estrus response was $90 \%$ vs $80 \%$, whereas, the interval to estrus was $44 \mathrm{~h}$ $v s .45 \mathrm{~h}$ for Awassi ewes treated with intravaginal sponges injected with and without antibiotic, respectively. In this study, the pregnancy rate for ewes received sponge impregnated with ciprofloxacin (G2) was significant higher than control (G1) and that received sponges containing combination of antimycotic and ciprofloxacin (G3). Indeed, there is a trend of improving the pregnancy rate by $33.33 \%$ (G2) and $17.65 \%$ (G3) higher than control (G1). In the same manner, the fecundity rate in G2 improved by $9.08 \%$ than G1 and by $7.14 \%$ than G3. Furthermore, the lambing rate was higher in G2 than G1 (control) and G3. These achieving results indicate that, antimicrobial containing vaginal sponge affects the reproductive performance in sheep. These results are in agreement with Nihat Ozyurtlu et al[30]. The declining in the pregnancy, lambing and fecundity rates in ewes treated by vaginal sponge without antimicrobial (control; G1) may be due to the sponge act as a foreign body that induces changes in the normal vaginal environment which favors bacterial growth causing vaginitis and could have a direct effect on sperm fertilization ability[1]. However, Vinoles et al.[31] claimed that the vaginitis had no effect on sperm survival and conception rate. Although, the number of vaginal bacteria returns to basal values at time of mating in this study and in others[5,32], changes in the normal vaginal flora composition such as the presence of opportunistic Enterobacteriaceae family were incriminated[1,7]. In the same line, Manes et al.[1] and Martins et al.[7] reported that E.coli was the most prevalent bacteria in ewes after device removal that reduced sperm motility through sperm adhesion and agglutination and caused important morphological changes that altered its function in spermatozoa[33]. The infiltration of biologically active substances (as reactive oxygen species) released by leukocytes in the vaginal epithelium as the course of the inflammatory response may act against the spermatozoa dysfunction contributing to fertility decrease, affecting the reproductive response and the fertility from the estrus synchronization treatments[5]. High levels of reactive oxygen species have been reported as responsible to structural, metabolic and functional alterations of spermatozoa[34]. Additionally, the action of lipopolysaccharides which produced as components of Gram negative bacteria[35] have been linked to infertility and pregnancy losses and could also have a negative effect on the viability and motility of spermatozoa[36]. In this sense of possible explanation, the antibiotic treatment only prevented the increase in the bacterial counts, but not the changes in the flora composition observed after the use of vaginal sponge. All these factors may explain the lower conception and fecundity rates obtained in control ewes.

In conclusion, the employ of intravaginal sponges containing progesterone analogue during estrus synchronization protocols in ewes caused increases in the presence of total bacterial count, changing the vaginal microflora and opportunistic pathogens, as well as vaginal fungus were stimulated inflammation of the vagina. Staphylococcus spp. was the most frequently recovered from the vaginal samples cultured, and all isolates had a high sensitivity to ciprofloxacin antimicrobials that measured control of vaginitis. The concomitant use of antibiotics is often suggested to reduce the undesirable effects caused by sponges, so if the choice is made to incorporate antibiotics, an antibiotic sensitivity test should be performed to select the appropriate compound(s). Vaginal sponges when injected with antimicrobial agents (ciprofloxacin with/without antimycotic) can improve reproductive performance (pregnancy and fecundity rates).

\section{Conflict of interest statement}

We declare that we have no conflict of interest.

\section{Acknowledgements}

Authors gratefully acknowledge and thanks prof. Dr. Rifaey for his assistance with fungus isolation and species identification, and also to Dr. Abd-Elkareem Mahmoud for assistance provided by ultrasonography examination for pregnancy diagnosis.

\section{References}

[1] Manes J, Fiorentino MA, Kaiser G, Hobor F, Alberio R, Sanchez E, et al. Changes in the aerobic vaginal flora after treatment with different intravaginal devices in ewes. Small Rum Res 2010; 94: 201-204.

[2] Muna NF. Oestrus synchronization in indigenous ewes using cloprostenol. Master thesis. Bangladesh Agricultural University; 2012.

[3] Abecia JA, Forcada F, Gonzalez-bulnes A. Hormonal control of reproduction in small ruminants. Anim Reprod Sci 2012; 130: 173-179.

[4] Menchaca A, Rubianes E. New treatments associated with timed artificial insemination in small ruminants. Reprod Fert Develop 2004; 16: 403-413.

[5] Suarez G, Zunino P, Carol H, Ungerfeld R. Changes in the aerobic 
vaginal bacterial mucous load and assessment of the susceptibility to antibiotics after treatment with intravaginal sponges in anestrus ewes. Small Rumin Res 2006; 63: 39-43.

[6] Sargison ND, Howie F, Mearns R, Penny CD, Foster G. Shiga toxinproducing Escherichia coli as a perenial cause of abortion in a closed flock of Suffolk ewes. Vet Rec 2007; 160: 875-876.

[7] Martins G, Figueira L, Penna B, Brando F, Varges R, Vasconcelos C, et al. Prevalence and antimicrobial susceptibility if vaginal bacteria from ewes treated with progestin-impregnated intravaginal sponges. Small Rumin Res 2009; 81: 182-184.

[8] Scudamore CL. Intravaginal sponge insertion technique. Vet Rec 1988; 123: 554 .

[9] Manes J, Fiorentino MA, Hozbor F, Paolocchi F, Alberio R, Ungerfeld R. Changes in the aerobic vaginal bacteria load and antimicrobial susceptibility after different oestrous synchronization treatments in goats. Anim Prod Sci 2013; 53: 555-559.

[10]Oliveira JK, Martins G, Esteves LV, Penna B, Hamond C, Fonsecac JF, et al. Changes in the vaginal flora of goats following a short term protocol of estrus induction and synchronization with intravaginal sponges as well as their antimicrobial sensitivity. Small Rumin Res 2013; 113: 162-166.

[11]Guerra MMP, Mota RA, Mergulhao FCC, Lima RF, Souza AF, Melo EH, et al. Study of the microbial flora and evaluation of the effectiveness of Gentocin (R) $40 \mathrm{mg}$ in the prevention of vaginal infection in dairy goats submitted to estrous synchronization. Hora Vet 2002; 22: 13-17.

[12]Koneman EW, Allen SD, Dowell VR, Sommers HM. Colour atlas and text book of diagnostic microbiology. 2nd ed. London: Lippincott Co.; 1983.

[13]Quinn PJ, Carter ME, Markey BK, Carter GR. Clinical veterinary microbiology. London: Mosby; 2011, p. 22-91.

[14]Cruickshank R, Daguid JP, Marmion BP, Swain RHA. The practice of medical microbiology. 12nd ed. London: Longman Group Ltd; 1975.

[15]Derbala MK. Diagnosis and treatment of endometritis in mare. $\mathrm{Ph} . \mathrm{D}$. Thesis. Beni-Suef Univ; 2013.

[16]Samson RA. A compilation of the aspergilli des cribed since 1965. Stud Mycol 1979; 18: 1-38.

[17]Majeed AF, Al-Rawi HM, Al-Kubaisi SMA, Al-Jumaily TMN. Vaginal bacteria flora concurred with vaginal sponges in black Iraqi goats. Iraqi J Veter Sci 2012; 26 (Supplement 4): 123-124.

[18]Carson CA, Reid-Smith R, Irwin RJ, Martin WS, McEwen SA. Antimicrobial resistance in generic fecal Escherichia coli from 29 beef farms in Ontario. Can J Vet Res 2008; 72: 119-128.

[19]Martins G, Figueira L, Penna B, Brand F, Varges R, Vasconcelos C, et al. Prevalence and antimicrobial susceptibility of vaginal bacteria from ewes treated with progestin-impregnated intravaginal sponges. Small Ruminant Res 2009; 10: 1016

[20]Penn B, Libonati H, Director A, Sarzedas AC, Martins G, Felipe Z, et al. Progestin-impregnated intravaginal sponges for estrus induction and synchronization infuences on goats vaginal flora and antimicrobial susceptibility. Anim Reprod Sci 2013; 142: 71-74.

[21]Scheibl P, Zerbe H. Effect of progesterone on the immune system in consideration of bovine placental retention. Dtsch Tierar Woch 2000; 107:
221-227.

[22]Lewis GS. Steroidal regulation of uterine resistance to bacterial infection in livestock. Reprod Biol Endocrinol 2003; 1: 117.

[23]Pineda MH. Female reproductive system. In: Pineda MH, editor. Veterinary endocrinology and reproduction. Iowa: Iowa State Press; 2003. p. 293-341.

[24]Glover DD, Larsen B. Longitudinal investigation of candida vaginitis in pregnancy: Role of superimposed antibiotic use. Obstet Gynecol 1998; 91:115-118.

[25]Xu J, Schwartz K, Bartoces M, Monsur J, Severson RK, Jack D, et al Effect of antibiotics on vulvovaginal candidiasis: A metro net study. J Am Board Fam Med 2008; 21: 261-268.

[26]Bluestein D, Rutledge C, Lumsden L. Predicting the occurrence of antibiotic-induced candidal vaginitis (AICV). J Fam Pract Res 1991; 11: 319-326.

[27]Amin JD. Effect of fluorogesterone acetate impregnated intravaginal sponges on vaginal bacterial flora of ewes. Nigerian J Anima Prod 1996; 23: $98-100$.

[28]Hayat HM, EL-Nour, Yassin MH, Amal AM, Ghoniem, Esmail ME Bacteriological and cytological vaginal findings and biochemical changes associated with different methods of synchronization in ewes. J Egypt Vet Med Assoc 2004; 64: 177-192.

[29]Martins LT, Neto PCS, Neto SG, Rauber LP, Bertolini M, Vieira AD, et al. Microbiological and functional evaluation of an alternative device for estrous synchronization in ewes. Cienica-Rural, Santa Maria 2010; 40 389-395.

[30]Ozyurtlu N, Yepylmen S, Kucukaslan Y. The effectiveness of using antibiotic with intravaginal sponge and duration of sponge treatments on the vaginal flora and fertility in anestrous ewes. J Anim Vet Advan 2008; 7: 723-727.

[31]Vinoles C, Paganoni AC, Milton BA, Driancourt AM, Martin GB Pregnancy rate and prolificacy after artificial insemination in ewes following synchronisation with prostaglandin, sponges, or sponges with bactericide. Anim Prod Sci 2011; 51: 565-569.

[32]Gatti M, Zunino P, Ungerfeld R. Changes in the aerobic vaginal bacterial mucous load after treatment with intravaginal sponges in anoestrous ewes: Effect of medroxiprogesterone acetate and antibiotic treatment use Reprod Dom Anim 2011; 46: 205-208.

[33]Schulz M, Sánchez R, Soto L, Risopatrón J, Villegas J. Effect of Escherichia coli and its soluble factors on mitochondrial membrane potential, phosphatidylserine translocation, viability, and motility of human spermatozoa. Fert Steril 2010; 94: 619-623

[34]Fraczek M, Kurpisz M. Inflammatory mediators exert toxic effects of oxidative stress on human spermatozoa. J Androl 2007; 28: 325-333.

[35]Yaniz JL, Marco Aguado MA, Mateos JA, Santolaria P. Bacterial contamination of ram semen, antibiotic sensitivities, and effect on sperm quality during storage at $15^{\circ} \mathrm{C}$. Anim Reprod Sci 2010; 122: 142-149.

[36]Gorga F, Galdiero M, Buommino E, Galdiero E. Porins and lipopolysaccharide induce apoptosis in human spermatozoa. Clin Diagn Lab Immunol 2001; 8: 206-208. 